\title{
Is the shaman indeed risen in post-Soviet Siberia?
}

\section{Introduction}

In his exhaustive study of 'shamanism' among the Altaic peoples in Southern Siberia, the renowned Soviet ethnographer Leonid P. Potapov contends that 'under the present conditions there are no remnants or survivals of Shamanism as such left in Altai'. What remains are legends and reminiscences, but these can no longer be told by people with personal experiences of Altaic 'shamans' (Altaic, sg. kam) and their rituals. According to Potapov, modern socialist culture has changed the minds of the Altaic peoples to the degree that they are now a materialistically thinking people, and 'shamanism' has completely disappeared. In addition, he contends that there are no prospects of its return after the deathblow dealt by Soviet anti-religious repression in the 1930s'shamanic' rituals were forbidden and ritual paraphernalia such as drums and costumes were expropriated by the authorities. ${ }^{1}$ Only 'shamans' knew 'shamanism' and since the former are gone, the latter can never return (Potapov 1991: 314-15).

Considering that Potapov in his study follows Altaic 'shamanism' through 1500 years, depicting it as a 'religion' and 'theology' which stayed more or less intact over the centuries, his statement seems more like a pious hope based on the Soviet vision of a society liberated from superstition, religion, and spiritual exploitation. Potapov himself delineates Altaic 'shamanism's' development from a 'state religion', allied with the ruling elite in the ancient Turkic empire, to a 'folk religion', associated with the family, the village and the clan, and focusing on healing and the securing of 'luck' in hunting, fishing and

1 For more on the Soviet 'struggle against shamanism' see e.g. Slezkine 1994: 226-30;

Vasil'eva 2000; Kharitonova 2006: 113-26; Sundström 2007: 122-98. To what extent alleged 'shamans' were arrested, incarcerated and executed during this campaign is still not entirely clear. The present article is written within the research project on the "Repression of "shamans" in the Soviet North from the late 1920 s through the 1950s: an archival study', which aims to establish what happened to those accused of being 'shamans'. The project is financed by the Swedish Research Council (Vetenskapsrådet). 
the breeding of livestock. Furthermore, as a folk religion it has, according to Potapov, recurrently been exposed to persecutions by proponents of competing religions such as Buddhism, Christianity, Islam and others (Potapov 1991: 84-107). From this perspective it might seem remarkable that 'shamanism' should not have survived 70 years of atheist repression, missionary work and the Soviet transformation of society.

Already by the time Potapov's book was published, during the very last months of the existence of the Soviet Union, there had, in fact, appeared a number of persons claiming to be 'shamans', with an ancestry dating from the time of 'shamans' of the first half of the twentieth century. These individuals were also part of organisations and movements promoting the revival of 'shamanism' in the autonomous Altai Republic ${ }^{2}$ (Halemba 2003: 175-6). In other parts of the former Soviet Union similar processes took place.

It may, thus, seem that Potapov was all wrong, or at least that his assessment was a bit rash. But it is little more complicated than that, I would say. As always, it is a question of definitions; of how we use and understand our concepts. To begin with I am sceptical that we can speak about a 'religion' existing as an essentially intact entity over several hundreds or thousands of years, as Potapov does. We must at least ask ourselves to what extent it has in that case been a uniform and constant phenomenon, considering all the different forms that it has taken under all the varying conditions in which it is supposed to have existed. To describe world-views and ritual practices as essentially intact is hardly possible even with formally institutionalised religions such as Buddhism, Christianity or Islam, if we look at the highly differing interpretations, practices and forms which those traditions have taken through the centuries, and in the various social, political and cultural contexts in which they have been found. When we, as observers from the outside, conceptualise Buddhism, Christianity and Islam as 'religions' that have existed for a number of centuries, it does not necessarily imply that they have constituted one and the same phenomenon at all times. It is rather the case that the temporal and spatial variations, as well as the competing, oftentimes contradictory, claims of representing an 'orthodoxy' or 'orthopraxy' within one or other of these 'religions', is generally understood. The degree of insight into these matters is, of course, deeper the more knowledge you have of these

The Altai Republic is not to be confused with the neighbouring region Altai Krai. Both areas are part of the Russian Federation, but while the Altai Republic has a considerable ethnic Altaic population (33.5\%), Altai Krai is almost exclusively inhabited by Russians and other descendants of European immigrant groups (Germans, Belarusians, Ukrainians). 
cultural expressions. Despite this insight it can be justified to use concepts such as 'Buddhism, 'Christianity' or 'Islam' in our descriptions, for the simple reason that the practitioners of these religions do so themselves. Then you have at least described a self-identification, even if that does not mean that all those who define themselves as Buddhists, Christians or Muslims are recognised as such by other Buddhists, Christians and Muslims; or that they all understand the concept in the same way.

With the concept of 'shamanism' things are different. To my mind, it is not possible to establish an ancient, more or less intact, Altaic 'shamanism' surviving over the centuries in the way described by Potapov. In that case, of course, I must agree with him when he claims that the indigenous worldview and ritual practices of the Altaians during the first half of the twentieth century have disappeared. Nevertheless, I would contend that today, in postSoviet Altai, as well as in many other parts of Siberia, shamanism exists in the same sense that there is Buddhism, Christianity and Islam in the region. This conclusion might seem peculiar, but in the following I will try to explain what I mean.

Before I move on I would just like to mention that my survey here of present day shamanism in Siberia is mostly based on other scholars' investigations and only to a limited extent on my own experiences of it.

\section{The 'shamanists'}

The Altaians were far from being the only group in the Soviet Union that was regarded as including practitioners of 'shamanism'. In the expanding empire that the Russian Tsars, ever since the sixteenth century, had been building, and which the Bolsheviks took over, there were more than 30 peoples, or ethnic groups, that the Russians considered as traditionally being 'shamanists'. These peoples inhabited northernmost Russia, Siberia and the Far East. ${ }^{3}$

However, linguistically, culturally, economically and historically these peoples do not form a homogeneous group. The various peoples spoke quite

3 Since the designation Siberia in former times-as well as today in the non-Russian speaking world-includes both Siberia proper and the Far East, and since the indigenous peoples of northern Russia (the Sami and the Nenets) both linguistically and culturally have much in common with some groups living to the east of the Urals, I will in the following, for the sake of brevity, refer to these peoples as the 'Siberian peoples' or the 'indigenous peoples of Siberia'. It is only for the Sami that this categorisation is somewhat inappropriate. 
separate languages, belonging to completely different language families - the Eskimo-Aleutan, the Chukotka-Kamchatkan, the Altaic and the Uralic. In addition, there are a couple of isolated languages, Nivkhi and Ket, for which no relationship to any other language family has been found.

The traditional ways of life of these peoples, up until the first decades of the twentieth century, may have shared some similarities at a general level. They were hunters, fishermen, gatherers and stock-breeding nomads or seminomads. But looking more closely at their economies, you find an array of varying ways of subsistence: sea mammal hunting on the ice coast; wild reindeer hunting on the tundra; reindeer breeding; fishing in lakes and rivers; hunting for elk, either for consumption or as fur-bearing animals for trade; horse, cattle, goat, or sheep breeding. These peoples also held widely varying world-views and mythologies-closely interwoven with the particular people's specific history and geographical surroundings-as well as locally elaborated rituals engaging locally acknowledged invisible powers. Moreover, these world-views and ritual practices varied between clans and other groupings within one and the same ethnic group, depending on social, economic and political circumstances. Not least, this kind of variety prevailed between the peoples' most prominent religious experts, those who have been ascribed the epithet 'shamans'.

What all these ethnic groups more decisively had in common was their relationship to Russian power. Ever since they were incorporated into the Russian Empire they have been colonised groups, gradually becoming minorities in their own home countries. ${ }^{4}$ Like many other colonised groups in other parts of the world they have experienced being ruled and defined by authorities who reside far away. These authorities have generally had a quite superficial understanding of their situation and have seldom given priority to their needs.

Since the 1920s the Soviet government distinguished one particular category among the indigenous peoples of Siberia. These, among themselves very different peoples, were called the 'small' or 'small-numbered peoples of the North, Siberia and the Far East'5, since each group consisted of comparasubjected to Soviet-Russian sovereignty until 1944. Today the Tuvinians constitute the majority ( $77 \%$ ) of the inhabitants of the autonomous Tuva Republic within the Russian Federation. The differences between the 'small-numbered' peoples and other indigenous peoples of Siberia (such as the Sakha, Buryats, Altaians and the Khakassians) are in this regard also considerable. 
tively few individuals. The smallest groups numbered but a couple of hundred (e.g. the Oroks and the Enets) while the larger ones (e.g. the Nenets and the Evenks) numbered 30,000-40,000, by the end of the Soviet period. Today the official designation for this category of peoples is 'small-numbered indigenous peoples. ${ }^{6}$ To qualify as such in a legal sense-and thus have access to, for example, state subsidies and other privileges - the group shall inhabit the homeland of their forbears, maintain a traditional way of life and subsistence, and number no more than 50,000 individuals. In the Russian Federation at present, 40 peoples belong to this category (Beach 2009, Newcity 2009).

When the indigenous peoples of Siberia, between the sixteenth and eighteenth centuries, were subjugated to Russian supremacy, they came to be defined as ethnic groups under particular ethnonyms. However, they were not always defined and named in the way the different groups delimited and called themselves. When Soviet authorities, in the 1920s, made partly new classifications of the peoples and assigned new ethnonyms for them, some groups became categorised together with groups that they had no knowledge of, or contact with, and whose language or dialect they did not understand (Vakhtin 1992: 8). In the Soviet standard work Narody Sibiri (Levin \& Potapov 1956: $19-20)^{7}$ it was pointed out that many of these 'peoples' consisted rather of different clans and tribes, and that the self-identifications varied a great deal within one and the same people. It was further contended that Tsarist ethnicity policies aimed at conserving these variations, thus impeding the ethnic consolidation process that, from a Soviet perspective, was considered to be a natural effect of historical development. In contrast, Soviet ethnicity policies, it is claimed, supported ethnic consolidation. Even if such a comment today might seem a bit paternalistic, it is important to mention that at the bottom of these Soviet administrative classifications and measures was, after all, a sincere aim to improve the lives of the indigenous peoples. The pragmatic simplifications made it possible to create written minority languages, carry out education in at least some of the small languages, and introduce minority rights that were to some extent ahead of their time (Sundström 2007: 129-43).

Besides the 'small-numbered peoples', Narody Sibiri also describes other, more large-numbered, indigenous peoples of Siberia, which were also considered to be traditional 'shamanists' (even if several of them in addition adhered to Buddhism or Christianity) — the Sakha (more well-known as the Yakuts), Buryats, Altaians, Khakassians and the Tuvinians. If the 'small-numbered

6 Korennye malochislennye narody.

7 The book was later published in English, as The Peoples of Siberia (1964). 
peoples' amounted to roughly 185,000 individuals altogether by the end of the Soviet era, the Buryats and the Sakha, for example, numbered around 420,000 each. By comparison with the small-numbered ones, the larger Siberian peoples were considered to be more strongly consolidated as ethnicities, and to have more highly developed cultures and economies. Some of them, such as the Altaians, historically had also governed state-like empires. But even when it came to these more 'developed' and 'consolidated' groups, the authorities lumped together groups with diverse identities and contrasting cultures and speaking distinct languages or dialects. ${ }^{8}$

The ethnic identities that were defined by the Soviet authorities gradually became the self-identities of the peoples themselves, and today the ethnonyms that were given to them are oftentimes used as self-designations. In that process has also arisen a sense of affinity between the various Siberian peoples-an affinity that has its foundation in the Russian classification of them, as well as in common experiences of being colonised non-Russian peoples (inorodtsy) under Russian supremacy (Forsyth 1992: 363). When the Soviet Union collapsed, the small-numbered peoples organised themselves into the Russian Association of the Indigenous Peoples of the North, Siberia and the Far East (RAIPON). ${ }^{9}$

\section{'Shamans' and 'shamanism'}

Before the middle of the nineteenth century, the word shaman did not occur in most of the indigenous languages of northern Russia and Siberia. The exception to this was some Manchu-Tungus languages, for example Evenk, from which the very word is supposed to have its origin. It was German and Russian scientists, and later on also Russian-Orthodox missionaries, who in the eighteenth and nineteenth centuries began to describe the most prominent ritual specialists among the peoples of Siberia with the term shaman

8 Thus, e.g., the ethnicities the Kachas, Sagais, Beltirs, and Koibals were brought together under the common ethnonym the Khakassians, and the Altai-Kizhi, Telengits, Telesys, Teleuts, Chelkans, and the Tubalars were all classified as the Altaians. The Telengits, Teleuts, and the Tubalars are today recognised as distinct peoples, officially belonging to the small-numbered indigenous peoples of the Russian Federation (Donahoe et al. 2008: 996).

9 Assotsiatsiya korennykh malochislennye narodov Severa, Sibiri i Dal'nego Vostoka. One interesting detail in this context is that at the top of the RAIPON main page on the internet you find a picture of a ritual drum (see http://raipon.info/). 
(Znamenski 2003: $1 \mathrm{ff}$ ). ${ }^{10}$ In the various indigenous languages those religious functionaries that were to be classified as 'shamans' were designated with such terms as nojd (in Kildin Sami), tadebya (in Nenets), yə” (in Nganasan), chirta-ku (in certain Khanti dialects), ${ }^{11}$ oyuun for a male and udagan for a female (in Yakut), kam (among the Altaians), böö (in Buryat) and, of course, sama, saman or šaman (in Manchu-Tungus languages such as Nanai, Ulchi, Even and Evenk). These are merely examples of terms for religious specialists in the various languages, and there were usually subcategories as well as other categories of ritual experts besides these.

One could certainly argue for the existence of 'shamans' among these peoples however such a 'shaman' may be designated in different languages. This is, in fact, the explicit or implicit argument behind every employment of the term shaman outside its narrow Manchu-Tungus context. The important thing to note here is that the concept 'shaman' was created by so-called outsiders-by European visitors - and that this category served its functions in these visitors' approaches to the indigenous Siberian cultures. In the early scientific world-view, where nature as well as culture should be classified in order to be explained, 'shamans' became the foremost example of foreign peoples' 'charlatans' who duped their kinsfolk with 'superstition' and cheap tricks. Some observers considered them to be mentally unstable or unwell individuals making a career out of controlling their hysterical fits. To Christian missionaries they were, first and foremost, servants of the Devil. Depicting foreign peoples' spiritual and political leaders as frauds, maniacs or devilworshipers could be the only reason needed to motivate colonisation and the subjugation of the land and the peoples. There were, of course, other attitudes and assessments to be found among European travellers visiting the peoples of Siberia. In the Romantic reaction against Enlightenment rationalism, 'shamans' were at times idealised as the children of nature, with capacities to

10 The term was indeed already being used in Russian and other European literature during the second half of the seventeenth century, e.g. in Protopop Avvakum's relations of his encounters with the Evenks during his Siberian exile. However, according to Znamenski, at that time the term shaman was never used as a transcultural category, but specifically relating to the Evenk religious functionaries.

11 Indeed, the list of indigenous words for different types of Khanti 'shamans' is extensive (as it is in many other languages and cultures), something which has caused a debate among scholars as to whether the concept 'shaman' is at all applicable for Khanti religious experts (Siikala \& Ulyashev 2011: 176 f.). From my point of view, the Khanti case shows with clarity the coarseness of the concept 'shaman' and the way it obscures indigenous classifications and conceptions. 
make use of primordial mental faculties for creative solutions to a variety of problems related to health and prosperity. Some nineteenth century scholars also opposed far-reaching comparisons between 'shamans' in different cultures, maintaining that the differences between them were too many (see further Znamenski 2003, 2007).

Since 'shamans' and their activities were regarded as being such a dominant feature of indigenous Siberian cultures, 'shamanism' has in many cases been used as the designation for indigenous Siberian religions in their entirety. From the Siberian examples the concepts were later on generalised and applied to ritual specialists and religious practices in other parts of the globe, preferably to those found in cultures that formerly were classified as 'primitive' and which today are commonly known as 'indigenous'. Some scholars have argued that the concept of 'shamanism' is appropriate only for a subset of religious beliefs and activities within these religions. Thus, 'shamanism' could occur together, or side by side with other subsets within one people's religion. The different peoples' religions could vary among themselves, but 'shamanism' was supposed to be more or less uniform and constant cross-culturally and through the ages (see e.g. Hultkrantz 1973; Pharo 2011: 60).

In Russian we find two terms denoting what in English is translated as 'shamanism'-shamanstvo and shamanizm. Often these terms are used quite synonymously, but some scholars have seen crucial semantic differences between them. According to the Soviet ethnographer Lyudmila Khomich, shamantsvo usually refers to 'early religious beliefs associated with the presence of a particular person, who conducts cultic acts in the form of a certain ritual', while shamanizm, in contrast, applies to 'the totality of notions about the surrounding world and humans, which paved the way for the formation of a phenomenon such as shamanstvo' (Khomich 1981: 5). Shamanstvo would thus, as applied by some, be a more specific concept which narrows down certain beliefs and ritual acts in connection with a distinct ritual functionary, a 'shaman'. Shamanizm, on the other hand, would be a wider concept designating a type of world-view, and does not necessarily presuppose the presence of 'shamans'.

Descriptions of Siberian 'shamans' and their activities in ethnographic literature are strikingly similar. 'Shamans' oftentimes perform in a particular ceremonial costume and use drums in their rituals. Their rituals aim at securing success and prosperity in hunting, fishing, stock-breeding, human and animal procreation, health and so on. Ordinarily they preside over recurrent calendric and life-cycle rituals. They commonly possess the capability to do harm through ritual acts and words, and they master the arts of the interpretation of dreams and visions as well as divination. In the capacity of 
their proficiencies they are likely to be the authorities in their communities regarding a variety of issues. A would-be 'shaman' generally experiences a 'calling' in which he or she is beset by invisible beings which are presupposed within the world-view of the community. The process of being called to initiation as 'shaman' usually follows a certain pattern where the novice resists the call from the invisible beings, is cast into a state of confusion or disease, eventually capitulates to the will of the beings, recovers and takes on the new role. During rituals 'shamans' are described as undertaking out-of-the-body journeys to other places or dimensions of reality, where the invisible beings reside. Frequently, but not always, 'shamans' are described in this way.

Scholarly debates about the content and usage of the concept of 'shamanism' have been extensive, and they are likely to continue. There is neither the space, nor any need to account for these discussions and attempts at definitions here. ${ }^{12}$ However, it is worth mentioning that scholars define and use the concept differently, in the sense that they distinguish different components as being decisive for something to be defined as 'shamanism. Therefore the concept means slightly different things in different texts.

The type of definition that has been most common and has brought most attention-at least in American and Western European research-are the ones taking the performers' trance or ecstasy as the main criterion for distinguishing a ritual activity as 'shamanism'. Usually, this type of definition is associated with the Romanian historian of religion Mircea Eliade (1964), since it is through his work that it has been granted wide circulation. In Soviet ethnography-the research tradition that during the nineteenth century maintained the study of the indigenous religions of Siberia-the proposed 'shamanic' trance was not particularly conspicuous, even if it can be found in some authoritative scholars' definitions and descriptions (see e.g. Tokarev 1964: 283). One reason for the lack of a mention of trance or ecstasy in Soviet research was the anti-religious attitudes and the particular analysis of history, religion and society maintained by the Marxist-Leninist perspective. As a consequence the Soviet discourse focused on the 'shamans" social and political

12 An excellent, and comprehensive, survey of the history of the concept in both European and American research is one by Znamenski, 2007, where the important Russian research is also accounted for (something which regrettably is missing in many English language introductions). One of the more recent introductions is DuBois, 2009, which represents the American and Western European research tradition, where examples of 'shamanism' to a lesser degree are collected from northern Asia. For recent critical investigations of the concept 'shaman' and 'shamanism', see e.g. Pharo 2011 and Rydving 2011. 
roles rather than on their mental conditions (cf. Suslov 1931: 90-1). Another reason was probably that 'shamanism' was taken as such a self-evident feature of the indigenous Siberian cultures that the need for elaborated definitions, emphasising trance or other criteria, was not urgent. Yet another, most essential, reason was also that many of the Soviet ethnographers were not able to observe any state of trance, in the proper (psychological) sense, among 'shamans' during their field trips (see e.g. Gracheva 1983: 127; Potapov 1991: 100-4; Smoljak 1998). This fact could, of course, be due to the disappearance of trance in 'shamans' rituals during the twentieth century. But then again, if one counts trance as the crucial criterion for 'shamans' and 'shamanism', it would mean that it was not these phenomena that the Soviet ethnographers encountered and described.

In a widely cited article the French anthropologist Roberte Hamayon (1993) has objected to the focus on 'trance' or 'ecstasy' in studies and definitions of 'shamanism'. Her point is that it is not possible either to empirically prove, or in any meaningful sense examine, trance states among performing 'shamans'. In addition, she finds theoretical problems with taking altered states of consciousness as a point of departure when studying 'shamanism'. To attribute the 'shamans" behaviour during rituals to physiological and psychological factors implies that this behaviour is to be regarded first and foremost as dependent on nature, rather than on the cultural expectations that surround a 'shaman'. One consequence of the dominant focus on trance in research is, according to Hamayon, that 'shamans' have been psychologised and that the cultural and symbolic prerequisites for their behaviour have been seen as secondary. She distinguishes two main trends in the psychological approaches to 'shamanism' in the history of research. The first one she calls the 'mystical', which in many respects emanates from Eliade's work, albeit as an over-interpretation. Here 'shamanism' is understood as an 'exemplary kind of spiritual quest or a technique for seeking self-promoting "powers"'. It is this approach that has been cultivated within western neo-shamanism (see below). The second trend she names the 'psycho-pathological', in which it is contended that 'shamans' are mentally ill, but that they succeed in controlling their disorder, and subsequently are able to assist others that are mentally unstable (Hamayon 1993: 5-6).

Hamayon's conclusion is that a state of trance, in its psychological sense, is neither sufficient nor necessary for the ritual acts of 'shamans'. Neither is 'trance' sufficient or necessary for the understanding of these ritual acts by outsiders (i.e. researchers). What is essential is instead the 'shaman's' ability to have direct contact with the 'spirits' - the invisible beings presupposed in 
the world-view in which he or she acts. 'Shamans' never act in isolation, on their own authority, but always in the context of a collectively held symbolic universe, in which the 'shaman' plays a certain role-'the shaman "in trance" is like the actor on stage'. According to Hamayon, what is sufficient and necessary in order to understand 'shamanism' is therefore to understand the symbolic system that each 'shaman' plays about with (Hamayon 1993: 17). The Soviet ethnographer Anna Smoljak presents a similar conclusion when she states, concerning the Nanai belief system, that 'behind the shamanic faith proper there is a "background" of general religious and non-religious beliefs, without which it is impossible to understand the conceptions of the shamanist' (Smoljak 1998: 11). Despite their conviction that the ritual activities of Siberian ritual specialists must be understood and interpreted with regard to the specific social and ideological contexts in which each one of them performs, both Hamayon and Smoljak maintain the categories 'shaman' and 'shamanism'.

The case of the trance shows how difficult it is to find a common denominator which would unite all purported instances of 'shamans' and 'shamanism', and which at the same time would distinguish them from other phenomena. Even if there may exist several similarities between different descriptions of Siberian ritual specialists' rituals and world-views, it is still unclear how widely and frequently these similarities are to be found. Are they, for instance, more numerous than the differences? It is also a delicate task to establish whether seeming resemblances represent the 'essence', the indispensable features, in all the instances referred to as 'shamanism'. Further, there does not seem to be any agreement, among scholars, as to the origin or reason for the supposed similarities. Are they due to historical contacts and influences between peoples and cultures, or are they expressions of universal human responses to certain psychological, social or ecological factors? One question that is only too rarely asked is whether the resemblances found in descriptions of Siberian 'shamanism' depend on similarities between the authors of the descriptions, that is, between the European observers that have documented 'shamanism' for their contemporaries and for posterity. It is after all from them we have the major part of what information there is on 'shamanism' in history. What role does the describers' level of knowledge, underlying purposes and theories play for the categorisations made of these foreign peoples' cultural expressions? To demonstrate decisive similarities between these European observers' schooling, professions, social positions, gender, linguistic, religious and cultural affiliations is often a much simpler procedure than pointing out any similarities between Siberian 'shamans'. Since our knowledge about these 
scholars and missionaries, as a rule, is much more thorough, and the sources much more extensive, it is, of course, also easier to point out decisive differences between them in a nuanced way. ${ }^{13}$

My point here is not that there is a total lack of similarity between so-called shamans and the respective world-views they act within. Nor am I claiming that some sort of trance might not be an important part of many of their ritual performances. I also realise that it can serve certain analytical purposes to categorise partly similar, and at the same time partly dissimilar, phenomena with one common concept. But such an analytic concept must not be confused with a descriptive term. In such a case there is a risk that we understand different 'shamans' or 'shamanisms' more in the light of each other, rather than in the light of their respective specific contexts-this on no other basis than some, perhaps peripheral or superficial, resemblances (cf. Rydving 2010: 24-6). The important thing to call attention to here is that there was no notion of a common 'shamanism' among the Siberian peoples themselves a hundred years ago. Each indigenous group held world-views and ritual practices that were framed by the specific groups' historical, social, political, geographical and ecological situation, and they functioned as an attempt-good or bad-to handle this situation.

The variation that meets both the eye and the ear in terms like nojd, tadebya, yə’, chirta-ku, oyuun, udagan, kam, böö and sama can illustrate the variation that existed in the category of specialists collected under the heading 'shamans'. Even if this illustration, as pointed out above, does not rule out the possibility that we are dealing with, in some way or another, commensurable phenomena, it pinpoints yet another most important aspect-that these world-views and ritual activities were performed in a whole variety of quite separate languages. World-views are deeply ingrained in the languages in which they are communicated and performed (and we may well ask the question whether they exist at all outside the fabric of language). Thus, the persons that acted under these different designations did so in distinct linguistic, historical, social, political and cultural contexts. When outside observers classified them as belonging to one and the same category they distinguished one or a few features in the belief systems and activities under study, which they, as outsiders, considered being both common denominators as well as essential features in what 'shamans' believed and performed. Such a classification has, of course, its own linguistic, historical, social, political and cultural context. 
I use the quotation marks around the terms shamans and shamanism here to emphasise that they are derived from a certain context. This context is European and does not represent indigenous Siberian nomenclature or ways of conceptualising the phenomena referred to. One interesting observation, though, is that if the concepts 'shamans' and 'shamanism' were formerly exclusively used by outsiders to designate indigenous Siberian religious practices-despite the rich variations between them-the concepts have now been adopted by indigenous proponents of a revival of indigenous religions. For this late and post-Soviet movement there is a significant motivation to use the terms shamans and shamanism (or to be exact, since the words we are dealing with are used in Russian, shamany and shamanizm) without the quotation marks, since they in this context reflect self-designations (cf. Rydving 2011: 8). Not to put too fine a point to it, one could say that formerly there was no shamanism in Siberia, but now there is.

Thus, I employ quite the reverse strategy than the one chosen by V. I. Kharitonova (2009). She uses quotation marks when referring to post-Soviet shamanism, because she finds the attempts to 'artificially' revive traditional 'shamanism' to be a 'deformed' version of the latter. I do not find it possible, as an outsider, to establish who is a real shaman or not, in the way Kharitonova (2006: $231 \mathrm{f}$.) does on the basis of external and internal qualities in relation to the tradition; that is to say how well the individual follows concrete ritual traditions of the past and has certain 'supersensitive-extrasensorical abilities' (supersensitivno-ekstrasensornye sposobnosti). To this end the historical sources are much too imperfect. However, I do not for a second doubt that many 'shamans' of yesterday (as well as shamans of today) were creative personalities that possessed the (quite human) abilities to experience inner visions-which is the main conclusion drawn from the psychological and neurophysiological investigations referred to by Kharitionova (2006: 27-40). But the question still is what do these creative personalities create? Do they all create the same thing? Just as with the very wide category of 'artists', they may use highly variable forms of expression, produce quite different world-views and represent completely contrasting ideologies.

In the following I will try to give some details of how 'shamanism' came to be adopted as shamanism and what its expressions are. 


\section{The cultural-national renaissance}

Already by the time of perestroika in the 1980s, but with increasing intensity after 1991, the so-called cultural-national renaissance, or awakening (kul'turno-natsional'noe vozrozhdenie) swept the former Soviet Union. 'National' is in this case to be understood primarily as 'ethnic', rather than as relating to ideas of state-belonging and autonomy (even if such notions have been present in parts of the awakening). In short, the renaissance was about restoring and recapturing the ethnic minority cultures that were perceived to have been repressed under Communism, at the expense of a common Soviet culture. ${ }^{14}$ The Russian ethnographer Aleksandr Pika (1999) has coined the expression 'neo-traditionalism' to capture this striving for regaining and readapting pre-modern traditions of one's own ethnic group to contemporary society.

The ethnicity policy of the Soviet Communist Party was in many ways ambiguous. On the one hand 'ethnicity' was a category that Marxist-Leninist politics tried to overcome-'social class' was, of course, the main category in political analysis and strivings. The policy was therefore directed toward instilling a sense of internationalism (mezhdunarodnost') instead of nationalism. People were supposed to be Soviet citizens in the first place and only secondly belonging to a specific ethnic group. At the same time these attempts at 'Sovietisation' of the citizens' minds were often perceived as Russification by the minority groups, because of the apparent Russian-European traits in the modernisation that was carried through. On the other hand there were sincere attempts to strengthen the position of minority cultures and develop them within the framework of Soviet ideology. Through so-called native (tuzemnye sovety) or village councils (sel'skye sovety) even the 'small-numbered peoples of the North' were given the right to participate in decision-making on issues that concerned them. Traditional ways of sustenance were given some financial support from the government, even if they were also forced into collectivisation just like the Russian farmers. During the 1920 s and 1930 great efforts were made to create alphabets and writing systems for several of the indigenous languages. Education was developed at the periphery and the ini-

14 It serves to mention that a corresponding renaissance has taken place among indigenous peoples' in many places of the world over the last three or four decades of the twentieth century. To some extent this makes the Siberian cultural-national renaissance part of a globalised, and typically (post-)modern, phenomenon. However, the awakening of the peoples of the former Soviet Union had its specific prerequisites (cf. Siikala \& Ulyashev 2011: 319). 
tial aim-even if it never came about other than in exceptional cases-was that it was given in the native languages of the pupils. To this end measures were taken to create indigenous intelligentsias which could bring socialism and modernity to their compatriots. These intelligentsias consisted first and foremost of teachers and cultural workers posted at local schools, houses of culture and regional museums - the new infrastructure for the development of local cultures (see further Slezkine 1994: 221 ff.; Sundström 2007: 129-43). The support of the indigenous cultures also included efforts to maintain and develop traditional folkloric features such as handicraft, songs, dances, games and national costume, often displayed during state sponsored festivals. These policies contributed to what Aimar Ventsel (2005: 172) calls the 'canonisation of "tradition", that is to say, the elevation of selected features from a people's tradition as markers of that particular culture.

The different ethnic groups in the multi-ethnic Soviet Union were, according to Stalin's oft-cited motto, supposed to be 'socialist in content, national in form.' ${ }^{15}$ The ideal was, accordingly, that socialist society and ideology should be implemented in genuinely local, indigenous - and thus slightly varying-forms. Concretely the slogan was realised through the formation of folklore groups wearing special folk costumes, manufactured for this purpose, singing to the accompaniment of traditional musical instruments on important Soviet holidays such as the first of May or International Women's Day. However, since these folk costumes and performances had many common traits with, and to a considerable extent had been influenced by, typically Russian folklore dresses and performances, they appeared more as Soviet (or even Russian) even in form, and national perhaps only in colour, so to speak.

When the foundations of the Soviet Union began to shake, many in the local intelligentsias wanted to strengthen the 'traditions' that were believed to be characteristic of the region and its native inhabitants. The 1990 meant a revolution in which many of the Soviet ideals were reversed. Instead of internationalism and the blending of cultures (in favour of the Russian), the particularities of ethnicities were now emphasised. The contours of the ethnicities were already present in the 'canonised traditions' from Soviet times, just as there were local intelligentsias who could lead their renaissance, and an infrastructure with museums and houses of culture where manifestations of traditional and ethnic culture could be displayed. One important element in the 'socialist content' during Soviet times was, of course, atheism. As a con- 
sequence, when searching for new content to fill the national or ethnic forms, for many it felt natural to look for it in atheism's antithesis, religion.

Religion's recapturing of a place in post-Soviet Russian society after 70 years of repression is evident. It must be added, though, that the only thing that can be reliably verified is the growing number of religious institutions and organisations, concretely in the form of a number of newly opened places of worship and registered congregations. Whether religiosity or piety in different forms have become more common, sincere or intensified to the same extent is difficult to say, since these things are much more difficult to study. The frequency of participation in religious services and public religious rituals is still comparatively low in the Russian Federation today, even if it has increased since Soviet times (see e.g. Kääriäinen 1999, Filatov \& Lunkin 2006, Belyaev 2010). For the same reasons it is easier to establish that it was religious institutions and organisations that were successfully suppressed in the Soviet Union (Sundström 2007: 77-109). In the case of the indigenous Siberian religions the anti-religious campaigns were first and foremost directed towards the 'shamans'. However, 'shamanism' was in general considered to be extremely difficult to fight against, because it was not institutionalised in the same manner as Buddhism, Judaism, Christianity or Islam. There were no organisations to prohibit, no temples to shut down and no literature to ban (Sundström 2007: 120).

Shamanism is by no means the only religious movement that has germinated among the indigenous peoples of Siberia in post-Soviet times. There has been, and still is, a competition among several different religions in the different areas concerned. In the Sakha Republic (Yakutia) it has been competing with not only Russian Orthodoxy and Protestant Churches, but also with an indigenous (neo-)pagan movement partly hostile to shamanism (Filatov 2000: 118, 121). In the southern Siberian republics Altai, Khakassia, Buryatia and Tuva the choice has been between shamanism and Buddhism. In Altai (as well as in some parts of Khakassia) both of them have met with competition from the indigenous revivalist movement known as Burchanism, which has its roots back in the beginning of the twentieth century (Halemba 2003; Filatov \& Uzzell 2002: 108). In addition, it is not possible to say whether shamanism has won more adherents than, for example, Christian churches. Probably it has not, particularly compared with different Protestant movements from the West. In one sociological survey-referred to by Kharitonova (2006: 193)-a mere 3.6 per cent of the population in Tuva, one of the epicentres of the new shamanism, considered themselves to be adherents of shamanism. But there exists in Russia the time-honoured principle of a connection between cer- 
tain religions and certain ethnicities, according to which Russians are presupposed to be Orthodox Christians, while the Central Asian and some North Caucasian peoples are Muslims and so on.

As already mentioned, in the Altai Republic several organisations, devoted to the revival of the indigenous world-view and rituals, appeared. They gathered people for discussions on the mythology of the past and created for this purpose meeting places in houses of culture. Some of those engaged in these movements claimed to have shamanic gifts and be representatives of an age-old shamanism. In general, these organisations propose a life and society in harmony with nature, an ecological world-view and code of conduct which is thought of as the traditional Altaic attitude (Halemba 2003: 174-6). In Sakha we find a corresponding process with organisations for the reawakening of traditional rituals, healing methods, world-views, storytelling, songs, dances, costume and cuisine. One central feature in these movements is shamanism (Filatov 2000; Yamada 2004: 221). These processes are perhaps most conspicuous among the larger indigenous groups in eastern and southern Siberia. But they are also found among the smaller groups, such as the Khanti in northwestern Siberia. ${ }^{16}$

In an attempt to explain why the indigenous religion, together with shamanism, has been the object of revitalisation among the Khanti, the Russian historian Elena Glavatskaya (2004) outlines three elements upon which Khanti identity has been resting: the native language; the specific way of life (the economy based on hunting, fishing and reindeer herding, the traditional clothing, cuisine, types of dwelling etc.); and the religion. During Soviet times all of these were suppressed. From the 1950s the language was set aside in favour of Russian-even though some measures were taken to support the Khanti language(s) in schools and through the publication of literature in one of the main dialects (Kazym Khanti), Russian gradually gained ground. Today some 65-70 per cent of the $c a$ 25,000 Khanti speak the native tongue, but this proficiency is split between six main dialects and some thirty local idioms. After the Second World War the Khanti way of life was modernised

16 In the general cultural-national renaissance indigenous religion has also been reconstructed and revived among Finno-Ugric minorities in Russia west of the Urals, such as the Mari (see Toidybekova 1997, Luehrmann 2005) and the Udmurt (see Siikala 2000; Siikala \& Ulyashev 2011: 291-310). That traditional conceptions and ritual practices have been reconstructed, resurrected or 'recycled' (as Sonja Luehrmann puts is) does, of course, not mean that some of the elements revived completely lack a continuity with pre-to-post-Soviet times, rather the contrary. But forms of expression, and not least, the context have continually changed. 
and many of the nomads became settled and urbanised. It is no longer hunting, fishing, reindeer herding or even a rural settlement that unites all the Khanti people. During the 193 os and 1950 s the indigenous Khanti religion was fought against by the state under the slogan 'the struggle against shamanism. However, this struggle did not mean that the religion of the Khanti completely disappeared, at least not in rural areas and among those who continued a traditional livelihood. But it ceased to be public and was assigned to the private sphere, hidden from outsiders (Siikala \& Ulyashev 2011: 179). Consequently the religion was kept secret from the 'Russians'; it became associated with 100 per cent Khantiness, as well as 100 per cent non or even anti-Russianness. Since the native language proficiency was divided between several dialects, and since the traditional way of life in general had changed beyond recall, religion seemed to be not only the most convenient element to reintroduce, but also the only one that had the potential of uniting all the Khanti people (Glavatskaya 2004: 239-40). The Japanese anthropologist Takako Yamada finds a similar connection between the revival of ethnic identities and the renaissance of the indigenous religion among the Sakha. This was expressed quite explicitly by some Sakha politicians, who strove to reestablish traditional religious festivals in order 'to make Sakha traditional culture the core of people's mentality' (Yamada 1999: 131). However, at a more popular level, religious expressions can still be connected to, and show continuity with, traditional kinship systems and present the same conceptions of the invisible beings and afterlife as a century ago. This has been shown for example on segments of the Khanti population in rural areas (see Glavatskaya 2010: 129-30; Siikala \& Ulyashev 2011: 196).

Many of the proponents of ethno-political mobilisation and the revival of shamanism and other spiritual traditions belong to the indigenous urban intelligentsias of writers, cultural workers and academics. Quite a few are ethnographers with 'shamanism' and folklore as their special field of study.

That the ritual specialists that were designated earlier, in their own contexts, with words like tadebya, chirta-ku, oyuun, udagan, kam, sama and so on, are increasingly either labelled with the very word shaman, or understood as being an equivalent of the category 'shaman' by representatives of the new shamanism, could be interpreted as evidence of the incorporation of the definitions of the colonial power by the colonised. Possibly it could also mean that deep and detailed knowledge about the former 'unique' indigenous traditions has sunk into oblivion and become superficial. In that case, what has been revived in the new shamanism would be a simplified and generalised version of the historical indigenous religions. But we could also interpret the 
reawakening as a way to find a common identity and a common heritage, thus transcending ethnic borders that are no longer relevant. Today there are additional grounds for a common identification in the similar experiences of the different indigenous peoples during Russian colonialism and the Soviet period. As colonised peoples, forced into a minority position, the peoples of Siberia are uniting with other ethnic groups, all over the world, who in the same way identify themselves as colonised minorities and who today are defined as 'indigenous'. Significantly, many of these other indigenous peoples have also been ascribed as traditionally practising 'shamanism'.

\section{Shamanism's institutionalisation and religionisation}

Post-Soviet shamanism is, of course, a very disparate and complex phenomenon, with many different groups and individuals involved. Among these there are different aims, motivations and interests. There are also competing pretentions between different organisations and persons on representing an authentic 'tradition' (Lindquist 2006). The Russian-Swedish anthropologist Galina Lindquist writes that the new Siberian shamanism is a phenomenon in the making and is to be seen as 'a postmodern, post-colonial, social, and symbolic field' (Lindquist 2005: 265). Within this 'field' there are, however, many common traits, besides the fact that the participants identify their activities as shamanistic.

The Polish anthropologist Agnieszka Halemba contends that there is a distinct tendency towards 'institutionalisation' in the shamanistic renaissance movement in the Altai Republic. This is in contrast to the 'shamanism' of former days, which, unlike institutionalised Buddhism in Altai, was a constantly changing, undogmatic form of religion without a stable mythology (Halemba 2003: 171, 176). I would like to add to this that shamanism, in this process of institutionalisation-relying to a large extent on the organisational structures of Soviet society-has also become 'religionised' in the sense that it has been given forms that emulate well-established religions like Buddhism, Christianity and Islam. ${ }^{17}$ This institutionalisation and religionisation is mani-

In the Soviet Union it was frequently debated whether 'shamanism' was a 'religion' or not, and if so, in what sense. From the point of view of the authorities and academic research it was eventually concluded that it was a 'religion. This debate is most interesting and I am preparing an article on this issue. A preliminary observation that deserves to be mentioned here, though, is that the debate shows that the classification of 'shamanism' as a 'religion' was far from self-evident from a Soviet perspective, 
fested in, for example, the establishment of organisations and clinics, the publication of a certain kind of literature, the arrangement of sacred places and buildings for rituals and worship, the organisation of public rituals and feasts, and the creation of a network of national and international relations.

\section{Organisations, clinics and literature}

The shamanistic movements in the southern Siberian republics are probably the most highly developed and institutionalised. In, for example, Tuva and Buryatia, shamanism has been proclaimed an official traditional religion together with Buddhism and Russian Orthodoxy. The Russian ethnographer Valentina I. Kharitonova (2009: 153-4) argues that people structure their activities in ways they are used to since Soviet times, in organisations with a vertical, hierarchical structure. In Tuva a special kind of certificate is issued for shamans, confirming their right to perform shamanic rituals and to practise shamanic healing all over Tuva, and in parts of Russia and abroad as well. Interestingly enough, these certificates are shaped after the design of the membership cards for the Soviet Communist Party. ${ }^{18}$ Certified shamans also have the opportunity to co-operate with the modern healthcare and social services. According to official statistics, in 2005 there were 8 registered shamanic organisations and 57 certified shamans in Tuva (even if the estimated actual number is considered to be several hundred; Kharitonova 2006: 192). In Buryatia the shamanic organisation Khese khengereg has in a similar way listed known practising shamans. In Tuva, Buryatia and Sakha, shamanic associations are registered as 'religious' organisations, even while their activities to a large extent consist of individual therapies and cures for clients and participants in the shamanic courses given. But in their capacity as religious organisations they are entitled to tax reductions, access to certain public funding and acquire a more favourable visibility compared to other confessions (Lindquist 2005: 269; Pimenova 2009: 161).

In the courses offered by the different shamanic associations, the participants are taught traditional knowledge, the shamanic world-view and ideas, and learn the practicalities needed to become a folk healer or shaman. The

but that the categorisations finally agreed upon had thorough-going consequences for how the indigenous world-views and ritual practices were treated.

18 Such a certificate, issued by Mongush Kenin-Lopsan for an Ulug-Kham or Velikiy shaman, a 'Great Shaman', is reproduced in Kharitonova 2006: 166. Besides authorising the owner to perform rituals and healing, the document also gives him the somewhat indistinct right to 'freely demonstrate the strength and antiquity of Tuvinian shamanism? 
centres where these organisations have established themselves are framed as clinics where clients can consult shamans for physical, mental or spiritual afflictions. The growing interest in traditional knowledge and 'shamanism' has also generated scientific centres where ethnographical studies covering the old 'shamanism' are considered, and the contemporary shamanic practices are examined with modern medical and scientific methods.

Possibly the most well-known and influential personage in the contemporary shamanic movement in Tuva is Mongush Kenin-Lopsan (b. 1925). Already in the 1960 s he was a prominent Tuvinian intellectual, writer, poet and playwright, but also a trained ethnographer, educated in Leningrad, where he took a PhD in ethnography with a thesis on Tuvinian 'shamanism'. During Soviet times he was a member of the Communist Party. According to his own statement he belongs to a 'shamanic' family, his grandmother on his mother's side was an Ulug-Kham, 'Great Shaman', who for long periods of time was kept under arrest by Soviet authorities for 'anti-Soviet' and 'counterrevolutionary' activities. She is also supposed to have foretold for her grandson a future within 'shamanism'. Despite Kenin-Lopsan's advanced age he still keeps his office in the National Museum of Tuva, as well as his position as the head of the shamanic movement. He was one of the first proponents of a revival of shamanism in Tuva and started to this end the first shamanic organisation, Dungur (The Drum), in 1992. Dungur has later on hived off into sister organisations as well as rivalling groups and clinics. The head office of Dungur in Kyzyl, the capital of Tuva, was housed in a centrally located building, purposely bought by the government to accommodate the shamanic movement. The organisation is hierarchically structured, with Kenin-Lopsan as the president (he is sometimes called The Supreme [Verkhovnyi] Shaman of Tuva). As president it has been his ambition to make a record of all practising shamans and issue the organisation's special certificates. Despite the fact that he is training and authorising shamans, as well as practising some shamanic rituals and techniques, he has not taken the step to announce himself as a shaman (Lindquist 2005: 269; Kharitonova 2006: 165 ff.; Znamenski 2007: 350; Pimenova 2009: 169-70).

Lindquist (2005: 269) points out that the newly awakened shamanism in Tuva, for obvious reasons, lacks a literary canon that could compete with those of Christianity and Buddhism. Instead, the rich ethnographic Russian language literature has played the role of sources of knowledge about the indigenous world-view and rituals (cf. also Oshurkov 2009: 197-8). Not least Kenin-Lopsan's renowned scholarly work on the subject has served this function for reawakened shamans and shamanists. In addition, in the 1990 se 
started to write what could be defined as dogmatic and liturgical literature with titles such as Traditsionnaya etika tuvintsev (Traditional Tuvinian ethics) and Magiya tuvinskikh shamanov (The magic of the Tuvinian shamans). The same kind of normative and didactic literature has been published in other areas where post-Soviet shamanism has sprung up. From Buryatia can be mentioned the revealing title Tainstvo $i$ praktika shamanizma (The sacrament and practice of shamanism) by B. D. Bazarov. Just as when it comes to Western neo-shamanic literature, it is difficult to establish to what extent this kind of literature represents traditional academic research, creative selections from the global New Age supply, and old or new local traditions. Since many authors of these books and pamphlets are on the one hand trained academics, and on the other influenced by the new spirituality flourishing in Russia, as well as actively engaged in the cultural-national renaissance movement, these categories are easily blurred and merged.

One genre that at times comes close to the above-mentioned literature is that of the new textbooks intended for state schools in different areas of Siberia, and within which pupils are offered the opportunity to learn about their cultural heritage (see e.g. Popov \& Tsymbalistenko 2001, which covers Nenets and Khanti mythology in the Yamal peninsula). In some cases the timetabling of curricula in indigenous traditions have met with criticism for not keeping within the boundaries of the ideal for education in a secular state. During the 1990 s the Ministry of Education in Sakha launched a syllabus in 'spiritual education' (Balzer 2005: 62) and it also happened that shamans visited schools to teach both adults and children the traditional Sakha 'mentality' and world-view (Yamada 2004: 225). Sergei Filatov (2000: 119) also mentions that in some schools in Sakha a kind of 'pagan chapel' was set up and that in many of the houses of culture that were established in villages and small towns all over the republic during Soviet times, traditional prayers, rituals and ceremonies are now taught to the local people. Seen as examples of shamanism's 'religionisation', one could interpret these literary and educational measures as attempts at missionising the shamanic faith. However, the former president of the Sakha republic, Mikhail Nikolaev (ethnically Sakha), emphasised that all teaching of the indigenous spiritual traditions was strictly secular, merely aimed at rebuilding and reclaiming the national identity of the republic (Filatov 2000: 115).

Even if Nikolaev, in his capacity as president from the late 1980s and for most of the 1990s, emphasised the secular state (and, it seems, privately preferred the Russian Orthodox Church) he still actively supported the cultural, ethnic and spiritual renaissance along traditional Sakha lines. A national 
foundation, Vozrozhdenie ('Revival' or 'Rebirth'), was founded in 1991 with the purpose of re-instituting indigenous rituals and ceremonies, traditional healing and world-views, Sakha narratives, songs, dances, costume and cuisine. This was supposed to be done among all ethnic minorities in the republic, that is to say beyond the dominant Sakha, also the Evenk, the Even and the Yukaghir (Yamada 2004: 221). In 1996 the president also created the Akademiya dukhovnosti (Academy of spirituality) in which were represented scholars, writers, artists and other intellectuals, including the Russian Orthodox Bishop of Sakha. The assignment for the Academy was to re-awaken and develop spirituality amongst the multi-ethnic population, to maintain and enrich its cultural heritage, as well as raising the intellectual potential of the area. There were schisms within the Academy between those who considered the assignment to be a secular project and those who conceived it more in religious terms. As a result of this, political zealots of indigenous Sakha religion formed an independent organisation, Kut-Syur, ${ }^{19}$ as well as a nationalist political party, Sakha Kaskele. These two were far more radical than the president's initiatives, both in their religious and their nationalist attitudes. Even if the political powers at first encouraged them, by the end of the $1990 \mathrm{~s}$ the regime found them much too radical and sought to marginalise them (Filatov 2000: 116-20; Yamada 1999: 94-5).

The founder and leader of Kut-Syur, the linguist Lazar' Afanasiev, also wrote a book, which was to function as a guide to the indigenous Sakha religion. The title of the book, Aiyy uorete, ${ }^{20}$ can, in Afanasiev's usage, be translated approximately as 'Divine Teaching', but the concept is the same as the 'spiritual education' proposed by the Ministry of Education. Aiyylar (sg. aiyy), in the traditional Sakha world-view, is a term referring to benign, invisible beings belonging in the ninth, most remote, layer of heaven. In the eastern part of the ninth heaven, the supreme aiyy, Urung Aiyy Toyon, was supposed to reign. Urung Aiyy Toyon is traditionally identified with the sun. In his book Afanasiev describes a monotheistic mythology where the supreme

19 Kut-Syur can be translated as 'Soul-Power', a concept which, according to one contemporary urban shaman (udagan), 'signifies in general the ability to realise the potential that the human soul has' (Yamada 1999: 108). According to the founder of the organisation, Lazar' Afanasiev, this power is derived from the high god Aiyy. Thus, Kut-Syur also represents the divine that is inherent in every human being (Filatov 2000: 118). At the beginning of the 1990 another organisation, Sakha Omuk (The Sakha people) was founded. It had an agenda similar to that of Kut-Syur (Balzer 1993: 245).

20 The book is written in the Sakha language and has, to my knowledge, not been translated into any other language. 
aiyy — naming him Aiyy - is declared as a creator god who gives soul and life to all living beings. Interestingly, in his systematised doctrine, Afanasiev also dissociates himself from the 'shamanism' that was prevalent among the Sakha at the beginning of the twentieth century. This type of 'shamanism' dealt only with the curing of illnesses and the warding off of malevolent invisible beings, abassylar, belonging to the underground. Instead of the oyuun, the 'black shaman' of the nineteenth century, he advocates the revival of the aiyy oyuun, the 'white shaman', which is mentioned in sources from the seventeenth century. In Afanasi'ev's teaching the aiyy oyuun works as the indigenous analogue to the Christian priest. It is worth mentioning, in this context, that in the general shamanic movement in Sakha, not only in Afanasi'ev's branch, the handling of the abassylar of the underground, that is 'black' shamanism, is a rare occurrence. It is the 'white' shamanism that has been revived, and although healing is a characteristic trait, this is done mainly through sacrifices and rituals directed toward heavenly powers (Filatov 2000: 114, 118; Yamada 1999: 93, 136).

In Aiyy uorete an ethic is outlined; formulated as commandments to respect nature, work hard, further your own potential, speak the truth, attain the truth through study, protect your kut (soul), respect the commandments of Aiyy, and not to commit adultery, kill or destroy (Filatov 2000: 118). In the ethics that have been propagated both by the Sakha government and by the new shamans, the traditional Sakha way of life, as well as its religion, is depicted as being in a symbiotic relationship with nature and thus ecologically sound. The core of Sakha culture is considered to be worship of nature (Yamada 2004, 2011).

\section{Religious buildings, sacred places, feasts and rituals}

Early on Afanasi'ev's Kut-Syur spoke in favour of the construction of a temple in honour of Aiyy in central Yakutsk, the capital of Sakha. But in place of such an Aiyy Dieté, 'House of Aiyy', an Archie Dieté, 'House of Purity', was built in 2002. The new 'temple' was not located as centrally as was proposed by Kut-Syur-and perhaps more significantly, it was not placed as close to the new Russian Orthodox cathedral. Mentioned as a shrine, the building is constructed to replicate a traditional dwelling of the Sakha, a balagan, and local artists have adorned it with symbols and motifs from Sakha mythology. In this place dances and rituals are regularly performed. Among the most central rituals enacted here are purifying rituals in which the hearth (kiln) is the object of focus. It is there that Uot Ichchite, the master of fire, is supposed to reside. By the kiln particular prayers (algys) are pronounced to other 
mythological beings, and courses of study on the old world-view are taught. In the House of Purity naming rituals and weddings are conducted, but no burials or healing rituals. The house in many ways functions as a place where the kind of secular rituals created during Soviet times to replace the life cycle rituals carried out by the church, are performed (Balzer 2005). Similar plans to erect 'temples' or 'shrines' have been voiced in Buryatia and Tuva, none of which have been realised as of today, at least not to my knowledge. However, Kharitonova contends that the centres and clinics run by shamanic organisations in these republics in practice function as sacred places. Yurts or different types of sacrificial mounds where rituals are performed, have been erected in the yards of these urban centres. Local museums have also become sites for collective feasts and rituals (Kharitonova 2009: 156-8).

The traditional round dances (osuokhai) that are nowadays performed every Sunday in the House of Purity, were in former days carried out only in summer time, mostly in connection with the traditional midsummer celebration, ysyyakh. Since 1991 ysyyakh has been a national holiday held in many towns and villages all over Sakha. Occasionally it was also celebrated in Soviet times, but then as a secular festival with a 'socialist content' and involving Soviet symbols. In Yakutsk the House of Purity is responsible for the arrangement of the feast, which is held outside of town (Balzer 2005: 62). Ysyyakh has been known from ethnographic and historic literature since the seventeenth century, and there are also even older records suggesting that previously there were two important feasts held among the Sakha; aiyy ysyyakh at the summer solstice, and abassy ysyyakh in late autumn. During the latter, sacrifices were directed toward the abassylar. Formerly the name ysyyakh was also used for every major feast, for example weddings, when fermented horse milk, kumiss, was consumed and poured out in libations for different kinds of invisible beings (the majority of the Sakha were traditionally horse breeders).

As is the case with many major feasts it is not self-evident what is actually being celebrated. Ysyyakh is a New Year festival, since the new year is considered to begin with the arrival of summer. Just as in former days, the feast also serves social functions, strengthening the bonds of the community. In today's celebration you also find several particular rites, derived from the traditional religion: the greeting of the rising sun; the lighting of the fire, which is kept burning during the whole feast and onto which the ceremonial leader pours libations of kumiss to the aiyylar; prayers to Urung Aiyy Toyon are offered up, as well as to the 'spirit of the earth'; the round dance osuokhai is performed. In olden days there were particular dances where young women and young men were coupled together. In present day ysyyakh this rather corresponds 
to the modern discotheques arranged for the youth. Just as before there are today also many features that could be classified as secular, such as wrestling competitions, beauty contests and horse racing. Among the modern features we find for example exhibitions of indigenous arts and crafts, fashion shows, rock and folk music concerts. It is generally considered that in the remote past the ceremonial leader of the ysyyakh was an aiyy oyuun, a 'white shaman', even if the financer and organiser of a particular feast, generally a male elder, at times might perform this function. In contemporary ysyyakh celebrations, leading politicians, academics or well-known intellectuals are not uncommonly the ones leading the festivities and giving speeches. But reinstituted also is the white shaman, who leads prayers, lights the ceremonial fire and performs libations. To this end a new white costume has been designed for the aiyy oyuun (Yamada 1999: 123-32).

\section{Western neo-shamanism and 'world shamanism'}

At the same time as the revival of shamanism began among the indigenous peoples of Siberia, in the 1980s, a form of shamanism also sprang up in Moscow, Leningrad and other big cities in the Soviet Union. The shamanic practices and doctrines that reached Russian and other nationalities in Russian urban areas came from Western Europe and North America, where it had grown out of the multi-faceted New Age environment. The most prominent figure in this movement-most often referred to as neo-shamanism-was, and still is, Michael Harner, an American anthropologist who specialised in the Jivaro and Conibo peoples of the Amazon forests. His book The Way of the Shaman (1980) is a guide to how each and every one can practise shamanic techniques to further self-development and find harmony in life. Harner contends that he has accomplished a synthesis of all the 'shamanic' techniques from cultures all over the world, a synthesis he calls 'core shamanism. The lowest common denominator, the core, of 'shamanism' in general, Harner claims to be a certain altered state of consciousness, the 'shamanic state of consciousness', or trance. ${ }^{21}$ Following Harner's practical guide anyone can reach this state through drumming, dancing, singing and meditation techniques. With The Way of the Shaman and courses in the specified shamanic techniques, 'drum 
journeys' came to be practised not only by seekers from the western middle classes, but also by young people in the Soviet Union during perestroika. In the same way as the indigenous peoples of Siberia tried to fill their lives with a 'spiritual' content, an array of occult and esoteric teachings surfaced among urban intellectuals in Russia when the Communist Party, together with its proclaimed atheism, started to lose authority.

It is not easy to tell to what degree the neo-traditional movement working for a cultural-national renaissance among the peoples of Siberia would have picked up on their own shamanism without the inspiration from Western neo-shamanism. In any case, those who have headed post-Soviet shamanism in Siberia have studied not only Russian and Soviet ethnographies on their own cultures, and listened to recollections of peoples from the older generation remembering past and withered traditions. They have also learned from American and European New Age literature. Therefore, in many contemporary Siberian shamans' vocabulary we often find terms like energies, aura, chakra, karma, which are well-known from Western New Age terminology (Znamenski 2007: 353-61; Kharitonova 2009: 153).

Today there is a symbiosis between Western neo-shamanism and the neotraditional shamans of Siberia. From Moscow and St Petersburg seekers travel to the Siberian shamans to both learn and teach. Harner's organisation, the Foundation for Shamanic Studies has arranged conferences, seminars and courses in Siberia, notably in Tuva. It has also financially supported Tuvinian shamanic organisations. In 1994 Mongush Kenin-Lopsan was awarded the honorific title Living Treasure of Shamanism, together with a smaller lifeterm stipend, by Harner and his foundation. But it is not only Westerners who are travelling to Siberia to seek contact with indigenous shamans. Siberian shamans are travelling to Europe and America to give seminars and perform their art. In 1998 four of the most prominent Tuvinian shamanic practitioners, among them Kenin-Lopsan, were invited to California to teach students taking courses at the Foundation for Shamanic Studies. One of the participants of the course, Susan Grimaldi, remembers Kenin-Lopsan saying in his introductory speech and addressing Harner:

We think that we'll learn from each other: you from us and us from you. Together we'll work, so that world Shamanism will have progress and all of us will prosper together. I think that your Shamanism and Tuvan Shamanism together is what is called "world" Shamanism....When we 
join forces we will become much more powerful, and together we will move Shamanism forward all over the world. ${ }^{22}$

To what extent Kenin-Lopsan paraphrased 'world religion', 'world Communism' or 'world' as it is used in, for example, 'world music' when speaking about world shamanism is hard to tell. But without doubt he has joined Harner in the notion that shamanism is not only a religion for the Tuvinians, but a concern for all of humanity.

\section{The election of a Supreme Shaman of Russia}

In spring 2009 the Moscow based internet journal Shamanstvo (www. shamanstvo.ru) arranged 'the first popular election of a Supreme Shaman of Russia' (pervye narodnye vybory Verkhovnogo Shamana Rossii), an election that was open to every internet user between May and October of that year. In the list of eligible candidates were 188 names of practising shamans from the Siberian countryside as well as from the Russian metropolises. On the website were published short biographies explaining to what extent each and every nominee had shamanic descent or possessed other qualities that could be of merit for a representative of all shamans in the Russian Federation. The person who had organised the election, Olard Dikson (known also under his shaman name El'vil, 'The Wild Reindeer') was also nominated. Dikson has a long history in Moscow's New Age and neo-shamanic circles, and is the author of a whole range of practical guides in shamanism (written in the spirit of Harner). He has also co-operated with many shamans from the indigenous peoples of Siberia. ${ }^{23}$

The announcement of the election obviously met with a lot of negative response. Tuvinian and Altaic shamans criticised the arrangement for being a political act with the aim of controlling practising shamans. Tos Deer in Tuva, a sister organisation of Dungur, declared, according to the new agency TASSSibir', that a shaman is neither a 'president' nor a 'governor', nor a 'supreme religious office' to be elected. The organisation Belaya Vera (The White Faith) of the Altai Republic argued that shamanism is not a religion, but a completely individual practice. 
Dikson defended himself by pointing out that many shamanic associations, including Tos Deer, are official religious organisations with registered shamans and elected representatives exercising authority over their members. In Tuva we already find a recognised 'president' for Tuvinian shamans (KeninLopsan), and in addition several shamans have reached positions in the republic's government and authorities. The White Faith organises around 60 shamans, a fact which, to Dikson, does not look like pronounced individualism. ${ }^{24}$

One of the nominees, the Buryat 'celebrity shaman' Valentin Khagdaevwho, by the way, is sometimes called the 'Supreme Shaman of Olkhon Island' in Lake Baikal-protested in the press against his nomination and the whole procedure. In an interview he repudiates the idea of lumping all shamans together and imposing a hierarchy among them:

Each of the peoples [narodnost'] of Russia have their own shamans, with particular ancient traditions from their [respective] forebears, that are not mutually similar cultures. All shamans are different, and that's good. It is more interesting to live that way. There is no such concept as a supreme shaman of Russia. A shaman can have authority and be respected, [so] each of the peoples of Russia ought to have their own supreme shaman. ${ }^{25}$

Khagdaev also contends that you must differentiate between the 'traditional shamanism' among the indigenous peoples of Siberia and the 'new Russian neo-shamanism. The latter is a new invention, while the former is a centuries old religion and way of life that has never been forced upon anyone. To neoshamans shamanism is just a hobby and entertainment. 'How can they lay claim to the title Supreme Shaman of Russia? They have no authority over us us. We will never accept them. They are alien people to us.' ${ }^{26}$

Despite these statements by Khagdaev, it is interesting to note that he also seems to understand shamanism in a way that corresponds both to Harner's and other neo-traditionalist practitioners' characterisation of it, as the mother of all religions and as the Urphilosophie of mankind:

Shamanism is an ancient human system of knowledge which developed more than 10,000 years ago. It is the basis of all philosophical, mystical 
and religious ideas, since it preceded as well as influenced all of these to a greater or less degree. All of the peoples of the Earth, independent of where they live today or to which confession they belong, were shamanists, and some of them remain such to this day. ${ }^{27}$

In the end the election was cancelled, officially because of electoral rigging and attempts to arrange a competing election. ${ }^{28}$ Possibly the failed attempt at an election and the reactions it met with indicate that the Siberian shamanic movement will begin to emphasise particularity and differences between the indigenous traditions, as well as differentiate itself more from the 'European' neo-shamanism. Some scholars have also noted tendencies in recent years toward what Kharitonova labels 'de-shamanisation', that is that the interest in shamanism has decreased and several practitioners have either ceased their practices altogether or taken up other kinds of therapeutic methods (Kharitonova 2009: 160; cf. also Znamenski 2007: 352). At all events, the debate on the Supreme Shaman of Russia has given proof of variety and disunity within shamanism in Siberia and Russia.

\section{The varieties of contemporary shamanism and the question of authenticity}

Despite the tendencies toward institutionalisation and religionisation, as well as the uniformity that is reflected in the fact that the practitioners all conceptualise their activities as shamanism, this shamanism is expressed in many different ways and the concepts involved are also the subject of internal disagreements. In his studies of a contemporary Evenk shaman in the Buryat countryside, M. N. Oshurkov (2009: 201) finds that this shaman's activities are not, as opposed to the 'shamans' of former days, restricted to his own clan, and today he does not serve the function of unifying a certain group of people. In contrast to the old days, this shaman is in the service of anyone who looks him up-he runs a private practice where he cures individual clients. On the other hand, one could say that a shaman attracts larger and more heterogeneous groups of people. Lindquist $(2005 ; 2006)$ accounts for her own participation in a 'scientific-practical' expedition to Southern Siberia, which attracted

27 http://pressa.irk.ru/friday/2009/20/009001.html (accessed on 19 May 2011).

28 http://www.shamanstvo.ru/news_shaman/2009/news-35.htm (accessed on 20 May 2011). The announcement was written and published by Dikson's wife, Khakassian born Shonchalai Khovenmei. 
a multi-faceted group of researchers: scholars of various disciplines, psychologists, Russian and foreign representatives of different New Age therapies, members of indigenous peoples interested in their spiritual cultural heritage, and tourists. All of these participants had their own particular interest in shamanism, just as the performing (and at the same time studied) shamans had theirs. Many of these interests might seem trivial, such as consuming experiences of the exotic or earning money from performing colourful rituals. However, this does not exclude the possibility of sincere spiritual interests being present among all the involved, or that the new shamanism cannot create a sense of belonging and identity in both individuals and groups.

Besides the more organised expressions of shamanism, which have been described in this article, shamanism also exists as a more general theme in much of today's Siberian folklore, literature, art and craft; things that constitute important sources of income for many members of the indigenous peoples. In itself these folklore performances and arts can be interpreted as ways of ritually re-creating and manifesting ethnic identity. The practitioners do not necessarily invest more meaning in these performances and expressions than a desire to protect and develop their cultural heritage-tangible and intangible.

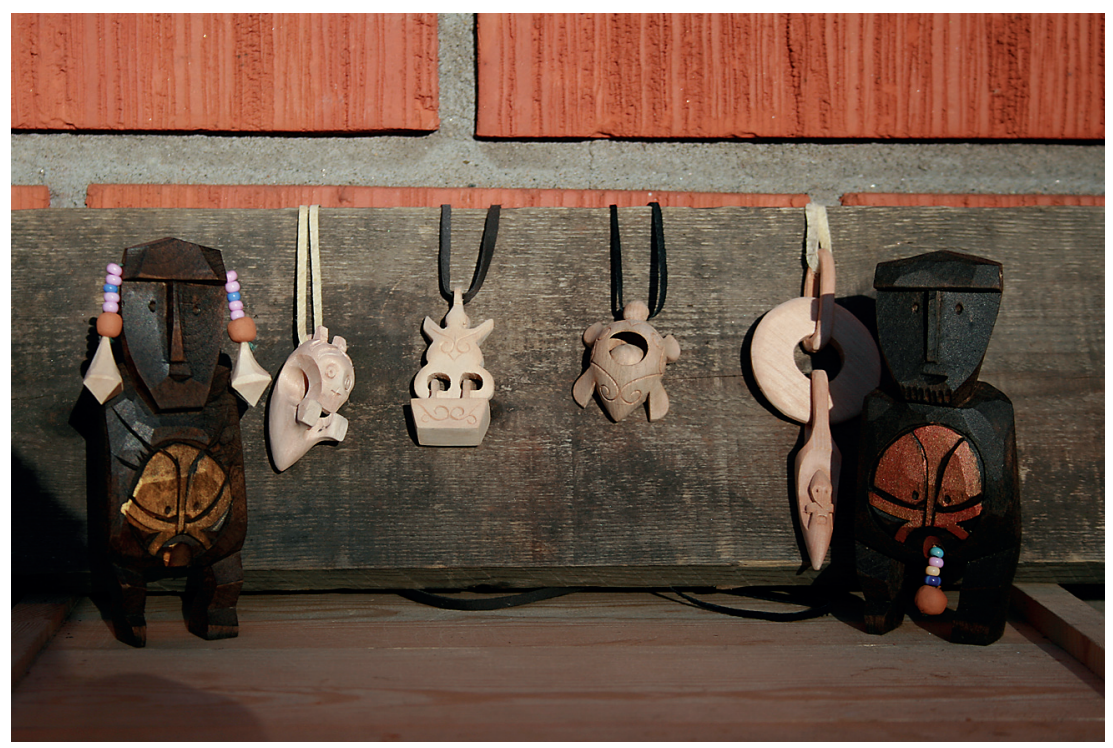

Contemporary Nanai handicraft, reproductions of amulets (middle) and figurines of the 'protectors of the family' (left and right) sold as souvenirs in the city of Khabarovsk. Photo by the author. 
In her account of the debate on the establishment of the House of Purity in Yakutsk, the American anthropologist Marjorie M. Balzer (2005) shows how controversial the new shamanism can be. In Sakha there are groups that she describes as 'fundamentalists' (e.g. some representatives of Kut-Syur), who claim that one should keep to the original teachings and practices (supposedly codified in the old ethnography). In opposition to these she finds the more politically pragmatically inclined, who strive to reinstitute a rather vague and openly defined cultural heritage, and those who consider all religious and nationalist motives for a renaissance of shamanism as a threat to the secular state.

There is also a general scepticism toward the practitioners of post-Soviet shamanism. These doubts are found among researchers, but perhaps more so among the older members of the indigenous peoples-those who have personal memories of the 'shamans' of former days or perhaps even in their youth practised the religion now said to be revived. In this debate questions about what or who is an 'authentic' shaman have arisen. As 'authentic shamans' are considered to be those who stand in an unbroken tradition, have learned the mythology and rituals directly from predecessors and have inherited an ascribed gift either by belonging to a 'shaman family' or can show certain signs of being 'chosen by the spirits'. Such 'authentic shamans' are at times supposed to exist in remote areas where traditional life, untouched by modernity, is still present (Lindquist \& Höjdestrand 2003: 131; Znamenski 2007: 357-8; Glavatskaya 2010; Siikala \& Ulyashev 2011: 176 ff.). Folk medicine and popular conceptions and rites probably exist in certain places in a more or less unbroken tradition, just as in other parts of the world, even if this is studied to a lesser degree than the shamanism that has entered the urban and political scene. Possibly there is also a greater general acceptance for such ideas and practices in post-Soviet times. But it is questionable whether these popular traditions are conceptualised as shamanism in the indigenous communities concerned.

The new shamans are well aware of the traditional demands of being able to show signs of being a 'chosen one.' Oftentimes they also refer to relatives that are supposed to have been 'shamans' in the past, but who were repressed and purged during the Stalin era. In the personal biographies of today's shamans you often find narratives about the crisis that became the turning point in their lives and that led to their present role. These crises are meant to correspond to the 'initiation diseases' the old 'shamans' went through, only the themes of the crises belong to the modern world, and include events such as car accidents, unemployment, or divorces (see e.g. Pimenova 2009). There 


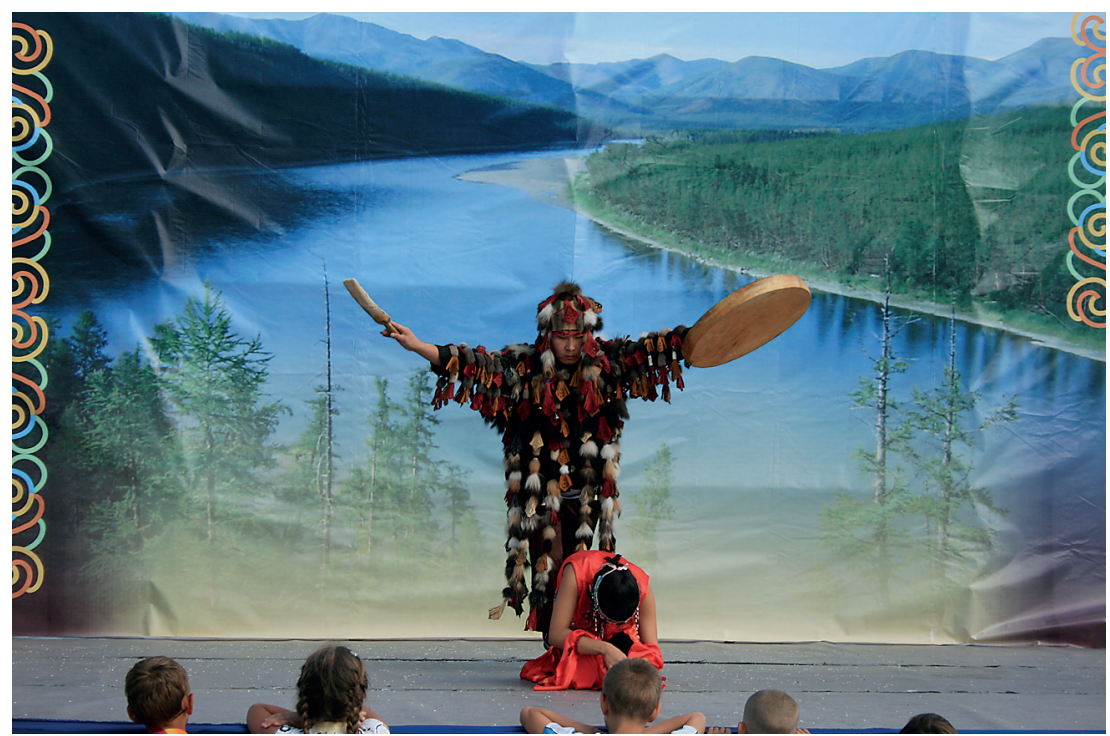

Contemporary artistic performance of Evenk shamanic dance during the folklore and art festival Zhivaya nit' vremen (The living thread of the ages) in Khabarovsk, August 2010. Photo by the author.

are also examples of those who can show physical signs of being chosen, such as the above mentioned Khagdaev, who has a thumb divided in two.

From an outsider's perspective it is not possible to decide upon such claims to authenticity, unless one accepts the premises of the world-view in question. If you do not share the conviction that the purported 'spirits' exist and have the capacity to influence people and events, it is just as impossible to accept or deny the claims of the shamans as it is to draw conclusions from a purported state of trance. Therefore, as an outsider you are confined to try to understand the external social, political and other expressions of shamanism. Looking at these expressions there is no doubt that present-day shamanism is in this regard just as authentic as ever the 'shamanisms' of yesterday. Shamanism today is framed by the historical, social, political, geographical and ecological situation of individuals and groups, and it functions as an attempt-good or bad-to handle this situation. 


\section{Concluding remarks}

The title of this article is a question. As may be obvious, the wording-'is the shaman indeed risen in post-Soviet Siberia?'-is borrowed from the Christian Easter liturgy. By the end of the Russian Orthodox Easter vigil, when the doors of the iconostasis are opened, the priest turns to the congregation and utters Khristos voskrese! (Christ is risen!), and the crowd replies Voistinu voskrese! (Indeed he is risen!). This is also the common Easter greeting among Christians in Russia, as well as in most parts of the world. But since the 1990s, with the fall of the Soviet Union, when the Church was regaining a position in Russian society, the phrase 'Indeed he is risen!' was lent additional meaning and weight among many Orthodox believers in Russia. With these words not only the resurrection of Christ was saluted, but also the return of priests, sanctuaries and Christianity itself after 70 years of atheist repression.

I would say that the answer to the question as to whether the shaman and shamanism are risen in today's Siberia is yes. But I would not say that they have been resurrected in the sense that the Christian wording may imply. The birth of shamanism as a practised religion, common to the indigenous peoples of northern Russia, Siberia and the Far East-as well as to other peoples on the globe-took place in the 1980 os and 1990s. Like all other religions it has, of course, its prehistory, as well as its internal controversies and differences. With a creative reformulation of a supposed tradition to fit present day conditions, Siberian shamanism has come into existence.

\section{References}

\section{Balzer, Marjorie M.}

1993 'Dilemmas of the spirit: religion and atheism in the Yakut-Sakha republic.' In: Sabrina P. Ramet (ed.), Religious Policy in the Soviet Union. 231-51. Cambridge: Cambridge University Press.

2005 'Whose steeple is higher? Religious competition in Siberia'. Religion, State \& Society 33 (1): 57-69.

\section{Beach, Hugh}

2009 'Introduction. In: Hugh Beach, Dmitri Funk \& Lennard Sillanpää (eds), PostSoviet Transformations: Politics of Ethnicity and Resource Use in Russia. 9-21. Uppsala Studies in Cultural Anthropology 46. Uppsala: Acta Universitatis Upsaliensis. 


\section{Belyaev, Demyan}

2010 " "Heterodox" religiosity in Russia after the fall of Communism: does it challenge “traditional" religion?' Religion, State \& Society 38 (2): 135-51.

Donahoe Brian, Joachim Otto Habeck, Agnieszka Halemba \& Istvan Sántha

2008 'Size and place in the construction of indigeneity in the Russian Federation.' Current Anthropology 49 (6): 993-1020.

\section{DuBois, Thomas A.}

2009 An Introduction to Shamanism. Cambridge: Cambridge University Press.

Eliade, Mircea

1964 Shamanism: Archaic Techniques of Ecstasy. London: Routledge \& Keegan. (First published in 1951.)

Filatov, Sergei B.

2000 'Yakutia (Sakha) faces a religious choice: shamanism or Christianity' Religion, State \& Society 28 (1): 113-22.

Filatov, Sergei B. \& Roman Lunkin

2006 'Statistics on religion in Russia: the reality behind the figures.' Religion, State \& Society 34 (1): 33-49.

Filatov, Sergei B. \& Lourens Uzzell

2002 'Khakassiya: sgustok religioznykh problem Sibiri' In: S. B. Filatov (ed.), Religiya $i$ obshchestvo. Ocherki religioznoi zhizni sovremennoi Rossii. 202-12. Moskva: Letnii sad.

\section{Forsyth, James}

1992 A History of the Peoples of Siberia. Cambridge: Cambridge University Press.

Glavatskaya, Elena

2004 'Religious and ethnic revitalization among the Siberian indigenous people: the Khanty case.' In: Takashi Irimoto \& Takako Yamada (eds), Circumpolar Ethnicity and Identity. 231-46. Senri Ethnological Studies 66. Osaka: National Museum of Ethnology.

2010 “"Posledniy shaman" iz lesov Trom’egana: k rekonstruktsii religioznogo landshafta surgutskikh khantov XX v'. Ural'skiy istoricheskiy vestnik 29 (4): 12330.

\section{Gracheva, Galina N.}

1983 Traditsionnoe mirovozzrenie okhotnikov Taimyra. Leningrad: Nauka.

Halemba, Agnieszka

2003 'Contemporary religious life in the Republic of Altai: the interaction of Buddhism and Shamanism.' Sibirica 3 (2): 165-82.

\section{Hamayon, Roberte}

1993 'Are "trance", "ecstasy" and similar concepts appropriate in the study of Shamanism?' Shaman 1 (2): 3-25.

\section{Harner, Michael}

1980 The Way of the Shaman: A Guide to Power and Healing. San Francisco: Harper \& Row. 
Is the shaman indeed risen in post-Soviet Siberia?

\section{Hultkrantz, Åke}

1973 'A definition of Shamanism.' Temenos 9: 25-37.

\section{Kääriäinen, Kimmo}

1999 'Religiousness in Russia after the collapse of Communism.' Social Compass 46 (1): 35-46.

\section{Kharitonova, Valentina I.}

2006 Feniks is pepla? Sibirskii shamanizm na rubezhe tysyacheletii. Moskva: Nauka.

2009 “'Shamanizm” v sovremmennoi Rossii: k problem vozrozhdeniya.' Etnograficheskoe obozrenie 6: 148-64.

Khomich, Lyudmila V.

1981 'Shamany u nentsev'. In: I. S. Vdovin (ed.), Problemy istorii obshchestvennogo soznaniya aborigenov Sibiri. 5-41. Leningrad: Nauka.

Levin, Maksim G. \& Leonid P. Potapov (eds)

1956 Narody Sibiri. Moskva \& Leningrad: Izd-vo Akademii Nauk SSSR.

\section{Lindquist, Galina}

2005 'Healers, leaders, and entrepreneurs: shamanic revival in South-Siberia.' Culture and Religion 6: 257-79.

2006 The Quest for the Authentic Shaman: Multiple Meanings of Shamanism on a Siberian Journey. Studies on Inter-religious Relations 30. Stockholm: Almqvist \& Wiksell International.

\section{Lindquist, Galina \& Tova Höjdestrand}

2003 'Jakten på den autentiska shamanen: om innebörd och tolkning på en sibirisk resa.' In: Christina Garsten \& Kerstin Sundman (eds), Moderna människor. Antropologiska perspektiv på samtiden. 113-36. Malmö: Liber.

\section{Luehrmann, Sonja}

2005 'Recycling cultural construction: desecularisation in post-Soviet Mari El'' Religion, State \& Society 33 (1): 35-56.

\section{Newcity, Michael}

2009 'Protecting the traditional knowledge and cultural expressions of Russia's "numerically-small" indigenous peoples: what has been done, what remains

\section{Oshurkov, M. N.} to be done.' Texas Wesleyan Law Review 15: 357-414.

2009 'On the shamanic worldview and practice among the Evenki of Buryatia: case study of a ritual held in the Kurumkan District /Răon/ of the Republic of Buryatia.' In: Hugh Beach, Dmitri Funk \& Lennard Sillanpää (eds), PostSoviet Transformations: Politics of Ethnicity and Resource Use in Russia. 187-202. Uppsala Studies in Cultural Anthropology 46. Uppsala: Acta Universitatis Upsaliensis.

\section{Pharo, Lars Kirkhusmo}

2011 'A methodology for a deconstruction and reconstruction of the concepts "shaman" and "shamanism".' Numen 58: 6-70. 
Pika, Aleksandr (ed.)

1999 Neotraditionalism in the Russian North: Indigenous Peoples and the Legacy of Perestroika. Circumpolar Research Series 6. Seattle \& London: University of Washington Press.

\section{Pimenova, Ksenia V.}

2009 'The emergence of a new social identity: trajectories and life stories of postSoviet shamans in the Republic of Tuva.' In: Hugh Beach, Dmitri Funk \& Lennard Sillanpää (eds), Post-Soviet Transformations: Politics of Ethnicity and Resource Use in Russia. 161-85. Uppsala Studies in Cultural Anthropology 46. Uppsala: Acta Universitatis Upsaliensis.

\section{Popov, Yu. I. \& N. B. Tsymbalistenko}

2001 Mifologiya, folklor i literatura Yamala. Uchebnik 5-7 klassy. Tyumen: Izd-vo Instituta problem osvoeniya Severa SO RAN.

\section{Potapov, Leonid P.}

1991 Altaiskii shamanism. Leningrad: Nauka.

\section{Rydving, Håkan}

2010 Tracing Sami Traditions: In Search of the Indigenous Religion among the Western Sami during the 17th and 18th Centuries. Institutet for sammenlignende kulturforskning, Serie B, Skrifter 135. Oslo: The Institute for Comparative Research in Human Culture, Novus forlag.

2011 'Le chamanisme aujourd'hui:constructions et déconstructions d'une illusion scientifique.' Études mongoles et sibériennes, centralasiatiques et tibétaines. URL: http://emscat.revues.org/index1815.html; DOI: 10.4000/ emscat.1815 (accessed on 22 December 2011).

\section{Siikala, Anna-Leena}

2000 'From sacrificial rituals into national festivals: post-Soviet transformations of Udmurt tradition.' In: P. J. Anttonen, A.-L. Siikala, S. R. Mathisen \& L. Magnusson (eds), Folklore, Heritage Politics and Ethnic Diversity: A Festschrift for Barbro Klein. 57-85. Botkyrka: Multicultural Centre.

Siikala, Anna-Leena \& Oleg Ulyashev

2011 Hidden Rituals and Public Performances: Traditions and Belonging among the Post-Soviet Khanty, Komi and Udmurts. Studia Fennica Folkloristica 19. Helsinki: Finnish Literature Society.

\section{Slezkine, Yuri}

1994 Arctic Mirrors: Russia and the Small Peoples of the North. Ithaca \& London: Cornell University Press.

\section{Smoljak, Anna V.}

1998 Der Schamane. Persönlichkeit, Funktionen, Weltanschauung. Die Völker am Unterlauf des Amur. Ethnologische Beiträge zur Cirkumpolarforschung 4. Berlin: Reinhold Schletzer Verlag. (First published in 1991.)

\section{Sundström, Olle}

2007 Kampen mot "schamanismen". Sovjetisk religionspolitik gentemot inhemska 
religioner i Sibirien och norra Ryssland. Studier av inter-religiösa relationer 40. Uppsala: Swedish Science Press.

2008 "Vildrenen är själv detsamma som en gud". "Gudar" och "andar" i sovjetiska etnografers beskrivningar av samojediska världsåskådningar. Nordliga studier, 1. Umeå: Umeå University.

\section{Suslov, Innokentii $M$.}

1931 Shamanstvo i bor'ba s nim. Moskva: Izdatel'stvo Komitet Severa.

\section{Svanberg, Jan}

2003 Schamantropologi i gränslandet mellan forskning och praktik. En studie av förhållandet mellan schamanismforskning och neoschamanism. Åbo: Åbo Akademis förlag.

\section{Toidybekova, Lidiya}

1997 Mariiskaya yazycheskaya vera i etnicheskoe samosoznanie. Joensuu: University of Joensuu.

\section{Tokarev, Sergey A.}

1964 Rannye formy religii i ikh rasvitie. Moskva: Nauka.

\section{Vakhtin, Nikolai B.}

1992 Native Peoples of the Russian Far North. London: Minority Rights Group.

\section{Vasil'eva, Nina Dmitrievna}

2000 Yakutskoe shamanstvo 1920-1930 gg. Yakutsk: Akademiya nauk Respubliki Sakha, IGI.

\section{Ventsel, Aimar}

2005 'The state's indigenous policy, the centrally planned cultural revival and native strategies of survival.' In: A. Leete \& Ü. Valk (eds), The Northern Peoples and States: Changing Relationships. 165-82. Studies in Folk Culture 5. Tartu: Tartu University Press.

\section{Yamada, Takako}

1999 An Anthropology of Animism and Shamanism. Budapest: Akadémiai Kiadó.

2004 'Symbiosis with nature: a message for the reconstructing of Sakha ethnicity and identity'. In: Takashi Irimoto \& Takako Yamada (eds), Circumpolar Ethnicity and Identity. 217-30. Senri Ethnological Studies 66. Osaka: National Museum of Ethnology.

2011 'Continuity and symbiosis of traditional cultures: from animism to a philosophy of ecology'. In: Takako Yamada \& Takashi Irimoto (eds), Continuity, Symbiosis, and the Mind in Traditional Cultures of Modern Societies. 145-51. Sapporo: Hokkaido University Press.

\section{Znamenski, Andrei A.}

2003 Shamanism in Siberia: Russian Records of Indigenous Spirituality. Dordrecht: Kluwer Academic Publishers.

2007 The Beauty of the Primitive: Shamanism and the Western Imagination. New York: Oxford University Press. 